\title{
Distinctive reactivity of $N$-benzylidene-[1,1'-biphenyl]-2-amines under photoredox conditions
}

\author{
Shrikant D. Tambe, Kwan Hong Min, Naeem Iqbal and Eun Jin Cho*
}

\author{
Full Research Paper \\ Address: \\ Department of Chemistry, Chung-Ang University, 84 Heukseok-ro, \\ Dongjak-gu, Seoul 06974, Republic of Korea \\ Email: \\ Eun Jin Cho* - ejcho@cau.ac.kr \\ * Corresponding author \\ Keywords: \\ 1,2-diamine; diversity; imine; photocatalysis; visible light
}

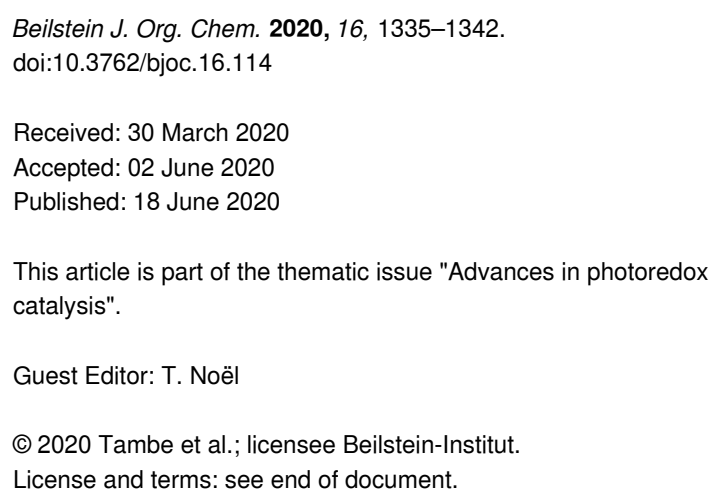

Beilstein J. Org. Chem. 2020, 16, 1335-1342. doi:10.3762/bjoc. 16.114

Received: 30 March 2020

Accepted: 02 June 2020

Published: 18 June 2020

This article is part of the thematic issue "Advances in photoredox catalysis".

Guest Editor: T. Noël

(C) 2020 Tambe et al.; licensee Beilstein-Institut.

License and terms: see end of document.

\begin{abstract}
A simple photocatalytic method was developed for the synthesis of unsymmetrical 1,2-diamines by the unprecedented reductive coupling of $N$-benzylidene-[1,1'-biphenyl]-2-amines with an aliphatic amine. The presence of a phenyl substituent in the aniline moiety of the substrate was critical for the reactivity. The reaction proceeded via radical-radical cross-coupling of $\alpha$-amino radicals generated by proton-coupled single-electron transfer in the presence of an Ir photocatalyst. On the other hand, symmetrical 1,2-diamines were selectively produced from the same starting materials by the judicious choice of the reaction conditions, showcasing the distinct reactivity of $N$-benzylidene-[1,1'-biphenyl]-2-amines. The developed method can be employed for the synthesis of various bulky vicinal diamines, which are potential ligands in stereoselective synthesis.
\end{abstract}

\section{Introduction}

The selective formation of distinct valuable compounds from the same starting material is a highly attractive divergent approach, though it represents significant synthetic challenges. Recent advances in visible-light photocatalysis, mediated by visible-light-absorbing photosensitizers, have allowed ready access to complex molecules in a controlled manner, where subtle differences in the reaction conditions opened up distinct reaction pathways [1-5].

Imines are versatile substrates that can be converted into various azo compounds, depending upon the reaction condi- tions [6-9]. In particular, the reactivities of $N$-benzylidenes have been extensively explored under visible-light photocatalysis [10-16]. $N$-Benzylidenes can undergo facile single-electron reduction to generate $\alpha$-amino radical intermediates, which can participate in diverse processes, depending upon the nature of the substrates and the reaction conditions (Scheme 1a). Various amine systems are generated from such intermediates via a wide range of processes, including hydrogen atom abstraction $[17,18]$, the addition to unsaturated compounds [19-21], radical-radical coupling [22-30], and cyclization reactions [3133]. Among these diverse applications, the Rueping group has 
a) transformations of imines

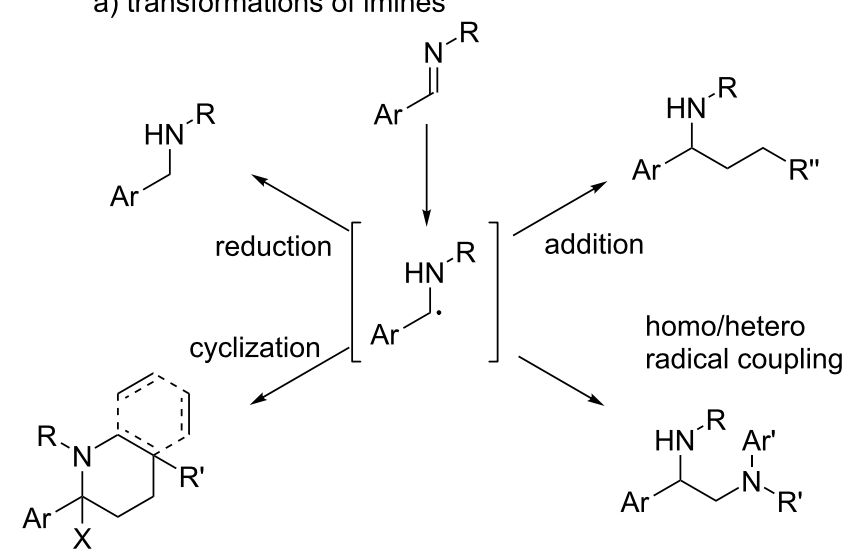

b) photocatalysis for 1,2-diamine synthesis

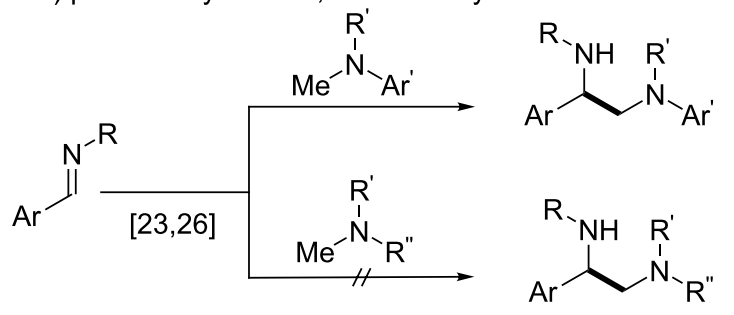

no report with aliphatic amines

c) this work: photocatalysis with aliphatic amines
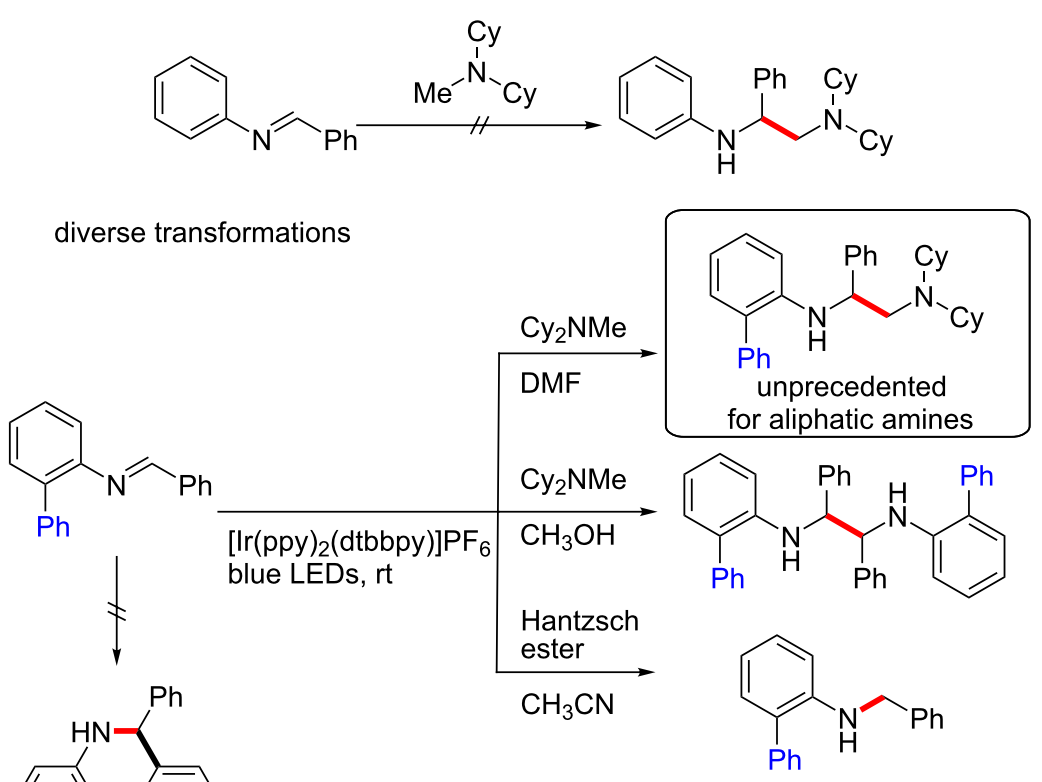

Scheme 1: Photocatalytic transformations of imines.

reported excellent examples of the reductive umpolung homocoupling of imines and heterocoupling with $\alpha$-amino radicals for the synthesis of symmetrical and unsymmetrical vicinal diamines (Scheme 1b) $[23,26]$. Notably, 1,2-diamines have widespread applications as core structures in a variety of natural products, pharmaceuticals, and agrochemicals [34-38] and are valuable ligands $[39,40]$ in stereoselective organic synthesis. Despite the availability of a plethora of synthetic methods for 1,2-diamines [41-45], the reported photocatalytic synthetic methods are mainly limited to aniline-based substrates and do not encompass aliphatic amines. 
We planned the synthesis of 1,2-diamine compounds having an aliphatic amine moiety by the intermolecular coupling of $\mathrm{N}$-benzylidines with aliphatic amines that not only act as coupling partner but also as electron donors in the photoredox cycle, and the results are reported herein. We began with the reaction of simple $\mathrm{N}$-benzylideneaniline. However, this substrate did not furnish the desired products under several different photocatalysis conditions, including those reported by Rueping. We hypothesized that the structural modification of the substrate might affect its reactivity, and to our delight, the introduction of an ortho-phenyl moiety on the $\mathrm{N}$-benzylideneaniline species provided the desired 1,2-diamine product, wherein the $N, N$-dicyclohexylmethylamine $\left(\mathrm{Cy}_{2} \mathrm{NMe}\right)$ acted as both the coupling partner and an electron donor in the photoredox cycle (Scheme 1c). It is likely that the presence of the additional phenyl group in the substrate stabilizes the $\alpha$-amino radical intermediate and modulates its reactivity [46,47]. In addition to the cross-coupled 1,2-diamines, we envisioned the generation of other valuable structural motifs via the careful control of the reaction conditions for the reaction of the biphenyl imine derivative $N$-benzylidene-[1,1'-biphenyl]-2amine.

\section{Results and Discussion}

With the initial results in hand, we attempted the optimization of the reaction conditions to improve the yield of the 1,2-diamine product (Table 1). Among the series of photocatalysts tested, ranging from the Ru/Ir polypyridyl complexes to organic

Table 1: Reaction optimization. ${ }^{\mathrm{a}}$

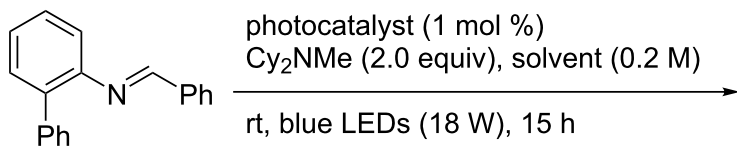

$1 \mathbf{a}$<smiles>CN(C)CC(Nc1ccccc1-c1ccccc1)c1ccccc1</smiles>

$2 \mathbf{a}$<smiles>c1ccc(-c2ccccc2NC(c2ccccc2)C(Nc2ccccc2-c2ccccc2)c2ccccc2)cc1</smiles>

$3 \mathbf{a}$

\begin{tabular}{|c|c|c|c|c|c|}
\hline \multirow[t]{2}{*}{ entry } & \multirow[t]{2}{*}{ photocatalyst } & \multirow[t]{2}{*}{ variation } & \multirow[t]{2}{*}{ solvent } & \multicolumn{2}{|c|}{ yield $(\%)^{b}$} \\
\hline & & & & $2 a$ & $3 a$ \\
\hline 1 & {$\left[\mathrm{Ru}(\mathrm{bpy})_{3}\right] \mathrm{Cl}_{2} \cdot 6 \mathrm{H}_{2} \mathrm{O}$} & - & $\mathrm{CH}_{3} \mathrm{CN}$ & 12 & 0 \\
\hline 2 & {$\left[\mathrm{Ru}(\mathrm{bpz})_{3}\right]\left(\mathrm{PF}_{6}\right)_{2}$} & - & $\mathrm{CH}_{3} \mathrm{CN}$ & 0 & 0 \\
\hline 3 & $\operatorname{Ir}(\mathrm{dFppy})_{3}$ & - & $\mathrm{CH}_{3} \mathrm{CN}$ & 0 & 0 \\
\hline 4 & $\operatorname{Ir}(\mathrm{ppy})_{3}$ & - & $\mathrm{CH}_{3} \mathrm{CN}$ & 3 & 25 \\
\hline 5 & {$\left[\operatorname{Ir}\left(\mathrm{dF}\left(\mathrm{CF}_{3}\right) \mathrm{ppy}\right)_{2}(\mathrm{dtbpy}) \mathrm{PF}_{6}\right.$} & - & $\mathrm{CH}_{3} \mathrm{CN}$ & 38 & 5 \\
\hline 6 & {$\left[\operatorname{lr}(\mathrm{dtbbpy})(\mathrm{ppy})_{2}\right] \mathrm{PF}_{6}$} & - & $\mathrm{CH}_{3} \mathrm{CN}$ & 60 & 11 \\
\hline 7 & TTPP & - & $\mathrm{CH}_{3} \mathrm{CN}$ & 0 & 0 \\
\hline 8 & crystal violet & - & $\mathrm{CH}_{3} \mathrm{CN}$ & 0 & 0 \\
\hline 9 & eosin-Y & - & $\mathrm{CH}_{3} \mathrm{CN}$ & 38 & 0 \\
\hline 10 & {$\left[\operatorname{lr}(\mathrm{dtbbpy})(\mathrm{ppy})_{2}\right] \mathrm{PF}_{6}$} & Cy ${ }_{2}$ NMe ( 1 equiv) & $\mathrm{CH}_{3} \mathrm{CN}$ & 14 & 55 \\
\hline 11 & {$\left[\operatorname{lr}(\mathrm{dtbbpy})(\mathrm{ppy})_{2}\right] P F_{6}$} & no $\mathrm{Cy}_{2} \mathrm{NMe}$ & $\mathrm{CH}_{3} \mathrm{CN}$ & 0 & trace \\
\hline 12 & no catalyst & - & $\mathrm{CH}_{3} \mathrm{CN}$ & 0 & 0 \\
\hline 13 & {$\left[\operatorname{lr}(\mathrm{dtbbpy})(\mathrm{ppy})_{2}\right] \mathrm{PF}_{6}$} & no light & $\mathrm{CH}_{3} \mathrm{CN}$ & 0 & 0 \\
\hline 14 & {$\left[\operatorname{lr}(\mathrm{dtbbpy})(\mathrm{ppy})_{2}\right] P F_{6}$} & - & $\mathrm{DCM}$ & 0 & 16 \\
\hline 15 & {$\left[\operatorname{lr}(\mathrm{dtbbpy})(\mathrm{ppy})_{2}\right] P F_{6}$} & - & DMF & $72(71)$ & 7 \\
\hline 16 & {$\left[\operatorname{lr}(\mathrm{dtbbpy})(\mathrm{ppy})_{2}\right] \mathrm{PF}_{6}$} & - & DCE & 22 & 11 \\
\hline 17 & {$\left[\operatorname{lr}(\mathrm{dtbbpy})(\mathrm{ppy})_{2}\right] \mathrm{PF}_{6}$} & - & DMSO & 37 & 6 \\
\hline 18 & {$\left[\operatorname{lr}(\mathrm{dtbbpy})(\mathrm{ppy})_{2}\right] \mathrm{PF}_{6}$} & - & dioxane & 50 & 13 \\
\hline 19 & {$\left[\operatorname{lr}(\mathrm{dtbbpy})(\mathrm{ppy})_{2}\right] \mathrm{PF}_{6}$} & - & TFE & 0 & 20 \\
\hline 20 & {$\left[\operatorname{lr}(\mathrm{dtbbpy})(\mathrm{ppy})_{2}\right] \mathrm{PF}_{6}$} & - & acetone & 22 & trace \\
\hline 21 & {$\left[\operatorname{lr}(\mathrm{dtbbpy})(\mathrm{ppy})_{2}\right] \mathrm{PF}_{6}$} & - & $\mathrm{EtOAc}$ & 36 & 8 \\
\hline 22 & {$\left[\operatorname{lr}(\mathrm{dtbbpy})(\mathrm{ppy})_{2}\right] \mathrm{PF}_{6}$} & - & $\mathrm{CH}_{3} \mathrm{OH}$ & 4 & $75(75)$ \\
\hline 23 & {$\left[\operatorname{lr}(\mathrm{dtbbpy})(\mathrm{ppy})_{2}\right] \mathrm{PF}_{6}$} & - & $\mathrm{DMF} / \mathrm{CH}_{3} \mathrm{OH}(1: 1)$ & 35 & 29 \\
\hline 24 & {$\left[\operatorname{lr}(\mathrm{dtbbpy})(\mathrm{ppy})_{2}\right] \mathrm{PF}_{6}$} & - & $\mathrm{DMF} / \mathrm{H}_{2} \mathrm{O}(1: 1)$ & 25 & 10 \\
\hline 25 & {$\left[\operatorname{lr}(\mathrm{dtbbpy})(\mathrm{ppy})_{2}\right] \mathrm{PF}_{6}$} & - & $\mathrm{CH}_{3} \mathrm{CN} / \mathrm{H}_{2} \mathrm{O}(1: 1)$ & 15 & 14 \\
\hline
\end{tabular}

aReaction conditions: $1 \mathrm{a}(0.1 \mathrm{mmol})$, under argon atmosphere. ${ }^{\mathrm{b}}$ The yields were determined by ${ }^{1} \mathrm{H}$ NMR spectroscopy using $1,3,5$-trimethoxybenzene as the internal standard, and the isolated yields are mentioned in parentheses. 
dyes, $\left[\operatorname{Ir}(\mathrm{dtbbpy})(\mathrm{ppy})_{2}\right] \mathrm{PF}_{6}$ was found to be the best and afforded $2 \mathrm{a}$ in $60 \%$ yield, along with $11 \%$ of the homocoupled product 3a (Table 1, entries 1-9). The amount of $\mathrm{Cy}_{2} \mathrm{NMe}$ was critical for achieving selectivity, and less than two equivalents of $\mathrm{Cy}_{2} \mathrm{NMe}$ gave greater amounts of the homocoupled product 3a (Table 1, entry 10). Control experiments showed that the photocatalyst, amine base, and light source are integral aspects of the reaction (Table 1, entries 11-13). DMF was found to be the best solvent and yielded 2a selectively (Table 1, entries 15-22). On the other hand, the homocoupled 3a was selectively obtained in protic solvents (Table 1, entries 19 and 22), and in particular, $\mathrm{CH}_{3} \mathrm{OH}$ showed a good reactivity and formed 3a in $75 \%$ yield. Unexpectedly, the cyclized product with the tethered phenyl ring proposed in Scheme 1c was not generated under any of the photocatalytic conditions evaluated.

With the optimized conditions in hand, the generality of the transformations was investigated using a wide variety of phenyl-substituted $N$-benzylideneaniline derivatives (Scheme 2). First, the $\mathrm{C}-\mathrm{C}$ cross-coupling process with $\mathrm{Cy}_{2} \mathrm{NMe}$ was

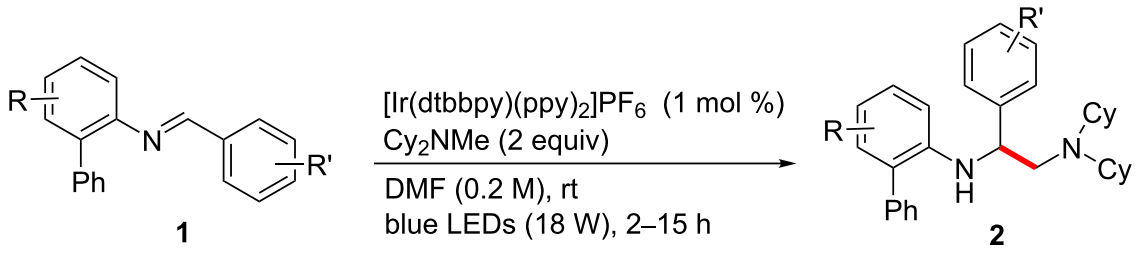<smiles>c1ccc(NC(CN2CC2)c2ccccc2-c2ccccc2)cc1</smiles>

2a, $71 \%$<smiles>O=[N+]([O-])c1ccc(C(CN(Cl)C2CCCCC2)Nc2ccccc2-c2ccccc2)cc1</smiles>

2b, $84 \%$<smiles>CC(CN(Cl)C1CCCCC1)Nc1ccccc1-c1ccccc1</smiles>

2c, $93 \%$<smiles>CC(C)(C)c1ccc(C(CN(C2CCCCC2)C2CCCCC2)Nc2ccccc2-c2ccccc2)cc1</smiles>

2d, $96 \%$<smiles>COc1ccccc1C(CN(C1CCCCC1)C1CCCCC1)Nc1ccccc1-c1ccccc1</smiles>

$2 \mathbf{e}, 80 \%$<smiles>ClN(CC(Nc1ccccc1-c1ccccc1)c1cccc2ccccc12)C1CCCCC1</smiles>

2f, $48 \%$<smiles></smiles>

$2 g, 85 \%$<smiles>Clc1ccc(C(CN(C2CCCCC2)C2CCCCC2)Nc2ccccc2-c2ccccc2)cc1</smiles>

2i, $76 \%$<smiles>Brc1ccc(C(CN(C2CCCCC2)C2CCCCC2)Nc2ccccc2-c2ccccc2)cc1</smiles>

2j, $77 \%^{a}$<smiles>Brc1ccccc1NC(CN(C1CCCCC1)C1CCCCC1)c1ccccc1</smiles>

2k, $65 \%^{a}$<smiles>Fc1ccc(C(CN(C2CCCCC2)C2CCCCC2)Nc2ccccc2-c2ccccc2)cc1</smiles>

2I, $96 \%$<smiles>FC(F)(F)c1cccc(C(CN(C2CCCCC2)C2CCCCC2)Nc2ccccc2-c2ccccc2)c1</smiles>

2m, $91 \%$<smiles>c1ccc(NC(CN(C2CCCCC2)C2CCCCC2)c2cccnc2)cc1</smiles>

2n, $45 \%$<smiles>c1ccc(-c2ccc(C(CN(C3CCCCC3)C3CCCCC3)Nc3ccccc3-c3ccccc3)cc2)cc1</smiles>

2o, $52 \%$<smiles>c1ccc(NC(CN(C2CCCCC2)C2CCCCC2)c2ccc3c(c2)OCO3)cc1</smiles>

$2 p, 36 \%$<smiles>Cc1ccc(-c2ccccc2)c(NC(CN(C2CCCCC2)C2CCCCC2)c2ccccc2)c1</smiles>

2q, $78 \%$<smiles>COc1ccc(-c2ccccc2)c(NC(CN(C2CCCCC2)C2CCCCC2)c2ccccc2)c1</smiles>

2r, $85 \%$<smiles>Fc1ccc(-c2ccccc2)c(NC(CN(C2CCCCC2)C2CCCCC2)c2ccccc2)c1</smiles>

2s, $83 \%$ 
explored, with variations of the benzylidene moiety. The reactions with both electron-donating (2b-2e) and electron-withdrawing substituents $(\mathbf{2 i}-\mathbf{2 m})$ proceeded well. Several functional groups, such as benzylic ones (2b and $\mathbf{2 c}$ ), ethers (2e), halogens (2i and 2l) [48-50], the medicinally important $\mathrm{CF}_{3}$ group (2m), and acetals (2p) were tolerated under these mild reaction conditions. The substitution pattern of the aryl groups, such as ortho (2c, $2 \mathbf{e}$, and $\mathbf{2 k})$, meta ( $\mathbf{2 m}$ and $\mathbf{2 p}$ ), and para substitution (2b-2d, 2g, 2i, 2l, 2o, and 2p), did not have any significant impact on the reaction outcome. The heteroaryl ring-bearing substrates (2n and 2o) also underwent the transformation, and furnished the valuable vicinal diamine products. The modifications on the aniline moiety were also suitable, and substrates with both electron-donating (2q and $\mathbf{2 r}$ ) and electronwithdrawing (2s) substituents underwent the cross-coupling with excellent reactivities. We also tried the transformation with aliphatic amines other than $\mathrm{Cy}_{2} \mathrm{NMe}$, such as TMEDA, TEA, and DIPEA. However, these reactions proceeded with a poor chemoselectivity and resulted in the formation of mixtures of several types of amine compounds.
A photochemical quantum yield, determined by using the standard ferrioxalate actinometry, was $83 \%$ for the radical crosscoupling between 1a and $\mathrm{Cy}_{2} \mathrm{NMe}$ (see Supporting Information File 1 for details).

Next, the homocoupling reactions of substituted $(E)$ - $N$-benzylidene-[1,1'-biphenyl]-2-amines were studied in $\mathrm{CH}_{3} \mathrm{OH}$ (Scheme 3) [51-56]. It is noteworthy that the resulting symmetrical 1,2-diamine compounds are potential ligands for a variety of organic transformations. The dimerization reactions proceeded well, regardless of the electron density or position of the substituent on the benzylidene moiety. Interestingly, the homocoupling process was highly stereoselective, resulting in the formation of only one diastereomer, probably due to the bulky substitution pattern of the substrates. The structure of the homocoupled 1,2-diamine product 3a was unambiguously confirmed using X-ray crystallography [57].

To further extend the diversity of the reactivity of the imines in this process, we also attempted the use of a reducing agent in

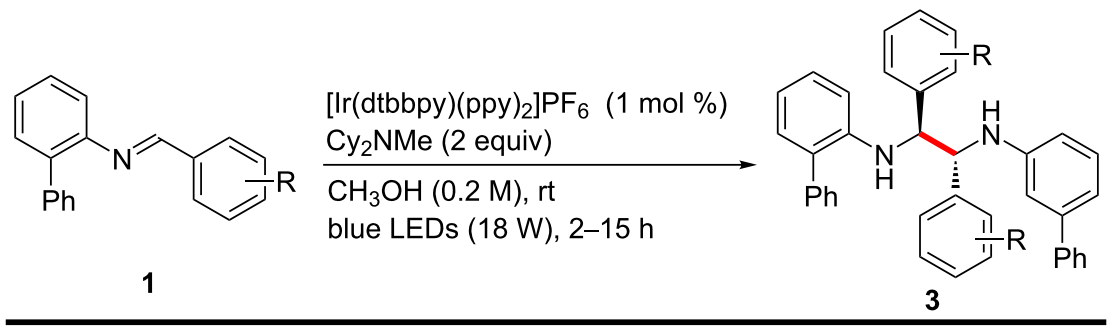<smiles>c1ccc(-c2cccc(NC(c3ccccc3)[C@H](Nc3ccccc3-c3ccccc3)c3ccccc3)c2)cc1</smiles>

3a, $75 \%$

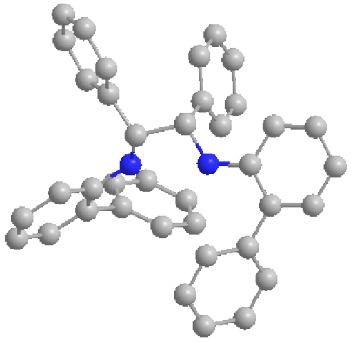

crystal structure of $3 \mathbf{a}$<smiles>CC(C)(C)c1ccc([C@H](Nc2ccccc2-c2ccccc2)[C@H](Nc2cccc(-c3ccccc3)c2)c2ccc(C(C)(C)C)cc2)cc1</smiles>

3b, $85 \%$<smiles>COc1ccccc1N[C@H](c1ccccc1OC)[C@@H](Nc1ccccc1P)c1ccccc1</smiles>

$3 c, 81 \%$<smiles>Brc1ccc(C(Nc2ccccc2-c2ccccc2)[C@H](Nc2cccc(-c3ccccc3)c2)c2ccc(Br)cc2)cc1</smiles>

3d, $78 \%^{a}$ 
the reaction of 1a. Pleasingly, the reaction of 1a with 2 equivalents of the Hantzsch ester in $\mathrm{CH}_{3} \mathrm{CN}$ produced the reduced amine product $4 \mathbf{a}$ in $67 \%$ yield (Scheme 4) [17,18,58-61].<smiles>c1ccc(Pc2ccccc2)cc1</smiles>

$1 \mathrm{a}$

\section{$\left[\operatorname{lr}(\mathrm{dtbbpy})(\mathrm{ppy})_{2}\right] \mathrm{PF}_{6}$}

Hanzsch Ester

(2 equiv)

$\mathrm{CH}_{3} \mathrm{CN}(0.2 \mathrm{M}), \mathrm{rt}$ blue LEDs $(18 \mathrm{~W}), 15 \mathrm{~h}$
$(1 \mathrm{~mol} \%)$

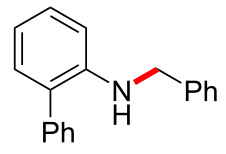

$4 a, 67 \%$
Scheme 4: Reduction of the imine $1 \mathrm{a}$ to the amine $4 \mathrm{a}$.

Based on these observations, a plausible reaction mechanism was proposed for the developed transformation (Scheme 5). Upon visible-light irradiation, the excited photocatalyst $\left[\mathrm{Ir}^{\mathrm{III}}\right]^{*}$ is formed and is reductively quenched by single-electron transfer from $\mathrm{Cy}_{2} \mathrm{NMe}$, resulting in the generation of the highly reducing $\left[\mathrm{Ir}^{\mathrm{II}}\right]$ species and the radical cation $\mathbf{A}$. To validate the reductive quenching pathway, we carried out Stern-Volmer quenching experiments (Figure S1, Supporting Information File 1). The emission intensity of the excited Ir complex significantly decreased in proportion to the concentration of $\mathrm{Cy}_{2} \mathrm{NMe}$, while it was much less affected by the concentration of $\mathbf{1 a}$, confirming the proposed working mode. The formation of $\mathbf{2 a}$ might be attributed to the proton-coupled electron transfer [6266] from $\left[\mathrm{Ir}^{\mathrm{II}}\right]$ to the imine $\mathbf{1 a}$, where the radical cation $\mathbf{A}$ donates a proton to $\mathbf{1 a}$ to form the $\alpha$-amino radical intermediates $\mathbf{B}$ and $\mathbf{C}$, which undergo cross-coupling to give the desired unsymmetrical vicinal diamine $\mathbf{2 a}$. On the other hand, in $\mathrm{CH}_{3} \mathrm{OH}$, 1a preferentially abstracts a proton from $\mathrm{CH}_{3} \mathrm{OH}$ rather than from $\mathbf{A}$, which, in turn, prevents the generation of the $\alpha$-amino radical $\mathbf{C}$ from $\mathrm{Cy}_{2} \mathrm{NMe}$, resulting in the homocou- pling of $\mathbf{B}$ to selectively form the symmetrical diamine product 3a.

\section{Conclusion}

We developed a divergent synthetic approach for the valuable 1,2-diamine motif from $N$-benzylidene-[1,1'-biphenyl]-2-amines by slight alterations to the reaction conditions. The in situgenerated $\alpha$-amino radical intermediates successfully underwent cross- and homocoupling to yield the unsymmetrical and symmetrical 1,2-diamines, respectively. The presence of the phenyl substituent at the aniline moiety was critical in the heterocoupling with aliphatic amines. Furthermore, the reduced amine product was also obtained by employing the Hantzsch ester. The developed method can be employed for the synthesis of bulky vicinal diamines with potential applications as ligands for stereoselective synthesis.

\section{Experimental}

An oven-dried resealable tube, equipped with a magnetic stir bar, was charged with the $N$-benzylidene-[1,1'-biphenyl]-2amine derivative $(0.3 \mathrm{mmol}),\left[\operatorname{Ir}(\mathrm{dtbbpy})(\mathrm{ppy})_{2}\right] \mathrm{PF}_{6}$ $(0.003 \mathrm{mmol})$, and $\mathrm{Cy}_{2} \mathrm{NMe}(0.6 \mathrm{mmol})$. The reaction mixture was purged with argon for $20 \mathrm{~min}$. Then, degassed DMF or $\mathrm{CH}_{3} \mathrm{OH}$ was added to the reaction mixture under inert conditions. The reaction mixture was stirred at ambient temperature for 2-15 h under visible-light irradiation with blue LEDs $(18 \mathrm{~W})$. The progress of the reaction was monitored by using TLC. Upon the completion of the reaction, the crude product was diluted with ethyl acetate and washed with brine. The organic layer was dried over anhydrous $\mathrm{MgSO}_{4}$ and concentrated in vacuo. The desired vicinal diamine product was purified by silica-gel column chromatography using hexane/ EtOAc as the eluent.

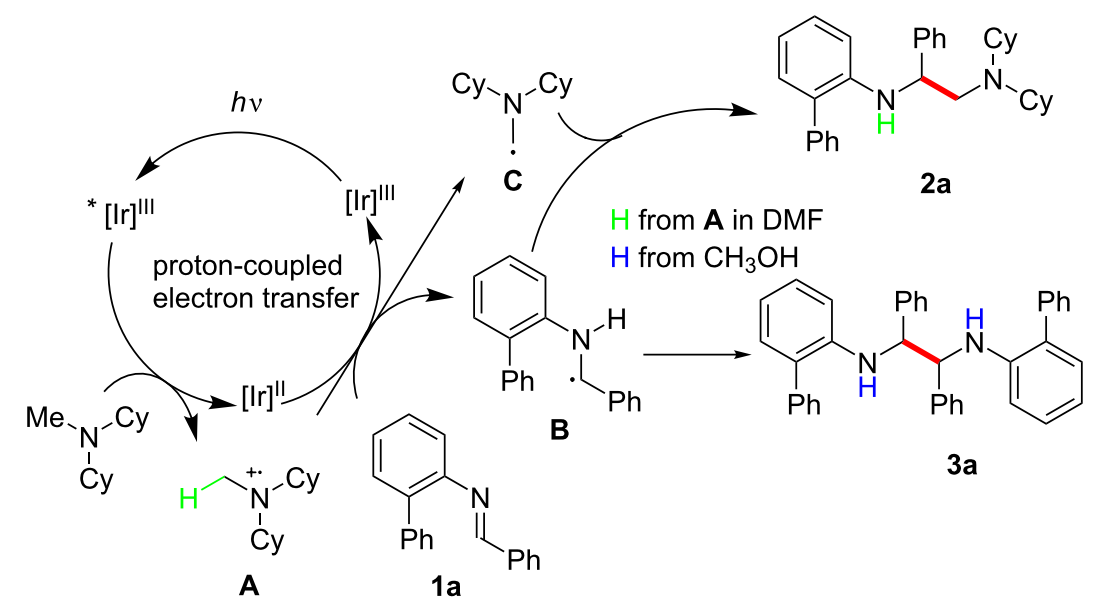




\section{Supporting Information}

\section{Supporting Information File 1}

Additional experimental details and analytical data.

[https://www.beilstein-journals.org/bjoc/content/

supplementary/1860-5397-16-114-S1.pdf]

\section{Supporting Information File 2}

Crystal data for 3a.

[https://www.beilstein-journals.org/bjoc/content/

supplementary/1860-5397-16-114-S2.cif]

\section{Funding}

This research was supported by Chung-Ang University Research Scholarship Grants in 2019 and by the National Research Foundation of Korea (NRF-2020R1A2C2009636).

\section{ORCID ${ }^{\circledR}$ iDs}

Eun Jin Cho - https://orcid.org/0000-0002-6607-1851

\section{Preprint}

A non-peer-reviewed version of this article has been previously published as a preprint doi:10.3762/bxiv.2020.35.v1

\section{References}

1. Cheng, Q.-Q.; Yedoyan, J.; Arman, H.; Doyle, M. P. J. Am. Chem. Soc. 2016, 138, 44-47. doi:10.1021/jacs.5b10860

2. Iqbal, N.; Jung, J.; Park, S.; Cho, E. J. Angew. Chem., Int. Ed. 2014, 53, 539-542. doi:10.1002/anie.201308735

3. Liu, Z.; Xu, H.; Yao, T.; Zhang, J.; Liu, L. Org. Lett. 2019, 21, 7539-7543. doi:10.1021/acs.orglett.9b02810

4. Mose, R.; Preegel, G.; Larsen, J.; Jakobsen, S.; Iversen, E. H.; Jørgensen, K. A. Nat. Chem. 2017, 9, 487-492. doi:10.1038/nchem.2682

5. Park, D. D.; Min, K. H.; Kang, J.; Hwang, H. S.; Soni, V. K.; Cho, C.-G.; Cho, E. J. Org. Lett. 2020, 22, 1130-1134. doi:10.1021/acs.orglett.9b04646

6. Miyabe, H.; Yoshioka, E.; Kohtani, S. Curr. Org. Chem. 2010, 14, 1254-1264. doi:10.2174/138527210791330477

7. Belowich, M. E.; Stoddart, J. F. Chem. Soc. Rev. 2012, 41, 2003-2024. doi:10.1039/c2cs15305j

8. Lei, J.; Huang, J.; Zhu, Q. Org. Biomol. Chem. 2016, 14, 2593-2602. doi:10.1039/c6ob00087h

9. Otero, A.; Chapela, M.-J.; Atanassova, M.; Vieites, J. M.; Cabado, A. G. Chem. Res. Toxicol. 2011, 24, 1817-1829. doi:10.1021/tx200182m

10. Cambié, D.; Bottecchia, C.; Straathof, N. J. W.; Hessel, V.; Noël, T. Chem. Rev. 2016, 116, 10276-10341. doi:10.1021/acs.chemrev.5b00707

11. Chatterjee, T.; Iqbal, N.; You, Y.; Cho, E. J. Acc. Chem. Res. 2016, 49, 2284-2294. doi:10.1021/acs.accounts.6b00248

12. Chen, J.-R.; Hu, X.-Q.; Lu, L.-Q.; Xiao, W.-J. Chem. Soc. Rev. 2016, 45, 2044-2056. doi:10.1039/c5cs00655d
13. Marzo, L.; Pagire, S. K.; Reiser, O.; König, B. Angew. Chem., Int. Ed. 2018, 57, 10034-10072. doi:10.1002/anie.201709766

14. Prier, C. K.; Rankic, D. A.; MacMillan, D. W. C. Chem. Rev. 2013, 113, 5322-5363. doi:10.1021/cr300503r

15. Romero, N. A.; Nicewicz, D. A. Chem. Rev. 2016, 116, 10075-10166. doi:10.1021/acs.chemrev.6b00057

16. Schultz, D. M.; Yoon, T. P. Science 2014, 343, 1239176. doi:10.1126/science.1239176

17. Guo, X.; Okamoto, Y.; Schreier, M. R.; Ward, T. R.; Wenger, O. S. Eur. J. Org. Chem. 2020, 1288-1293. doi:10.1002/ejoc.201900777

18. Xi, Z.-W.; Yang, L.; Wang, D.-Y.; Pu, C.-D.; Shen, Y.-M.; Wu, C.-D.; Peng, X.-G. J. Org. Chem. 2018, 83, 11886-11895. doi:10.1021/acs.joc.8b01651

19. Lee, K. N.; Lei, Z.; Ngai, M.-Y. J. Am. Chem. Soc. 2017, 139, 5003-5006. doi:10.1021/jacs.7b01373

20. Qi, L.; Chen, Y. Angew. Chem., Int. Ed. 2016, 55, 13312-13315. doi:10.1002/anie.201607813

21. Wu, G.; Wang, J.; Liu, C.; Sun, M.; Zhang, L.; Ma, Y.; Cheng, R.; Ye, J. Org. Chem. Front. 2019, 6, 2245-2249. doi:10.1039/c9qo00407f

22. Chen, M.; Zhao, X.; Yang, C.; Xia, W. Org. Lett. 2017, 19, 3807-3810. doi:10.1021/acs.orglett.7b01677

23. Fava, E.; Millet, A.; Nakajima, M.; Loescher, S.; Rueping, M. Angew. Chem., Int. Ed. 2016, 55, 6776-6779. doi:10.1002/anie.201511235

24. Hager, D.; MacMillan, D. W. C. J. Am. Chem. Soc. 2014, 136, 16986-16989. doi:10.1021/ja5102695

25. Jeffrey, J. L.; Petronijević, F. R.; MacMillan, D. W. C. J. Am. Chem. Soc. 2015, 137, 8404-8407. doi:10.1021/jacs.5b05376

26. Nakajima, M.; Fava, E.; Loescher, S.; Jiang, Z.; Rueping, M. Angew. Chem., Int. Ed. 2015, 54, 8828-8832. doi:10.1002/anie.201501556

27. Okamoto, S.; Ariki, R.; Tsujioka, H.; Sudo, A. J. Org. Chem. 2017, 82, 9731-9736. doi:10.1021/acs.joc.7b01838

28. Okamoto, S.; Kojiyama, K.; Tsujioka, H.; Sudo, A. Chem. Commun. 2016, 52, 11339-11342. doi:10.1039/c6cc05867a

29. Patel, N. R.; Kelly, C. B.; Siegenfeld, A. P.; Molander, G. A. ACS Catal. 2017, 7, 1766-1770. doi:10.1021/acscatal.6b03665

30. Uraguchi, D.; Kinoshita, N.; Kizu, T.; Ooi, T. J. Am. Chem. Soc. 2015, 137, 13768-13771. doi:10.1021/jacs.5b09329

31. Fava, E.; Nakajima, M.; Nguyen, A. L. P.; Rueping, M. J. Org. Chem. 2016, 81, 6959-6964. doi:10.1021/acs.joc.6b01006

32. Leitch, J. A.; Fuentes de Arriba, A. L.; Tan, J.; Hoff, O.; Martínez, C. M.; Dixon, D. J. Chem. Sci. 2018, 9, 6653-6658. doi:10.1039/c8sc01704b

33. Rono, L. J.; Yayla, H. G.; Wang, D. Y.; Armstrong, M. F.; Knowles, R. R. J. Am. Chem. Soc. 2013, 135, 17735-17738. doi:10.1021/ja4100595

34. Viso, A.; Fernández de la Pradilla, R.; García, A.; Flores, A. Chem. Rev. 2005, 105, 3167-3196. doi:10.1021/cr0406561

35. Lucet, D.; Le Gall, T.; Mioskowski, C. Angew. Chem., Int. Ed. 1998, 37, 2580-2627.

doi:10.1002/(sici)1521-3773(19981016)37:19<2580::aid-anie2580>3.0. $\mathrm{co} ; 2-1$

36. Bogatcheva, E.; Hanrahan, C.; Nikonenko, B.; Samala, R.; Chen, P.; Gearhart, J.; Barbosa, F.; Einck, L.; Nacy, C. A.; Protopopova, M. J. Med. Chem. 2006, 49, 3045-3048. doi:10.1021/jm050948+

37. Kano, T.; Sakamoto, R.; Akakura, M.; Maruoka, K. J. Am. Chem. Soc. 2012, 134, 7516-7520. doi:10.1021/ja301120z

38. Saibabu Kotti, S. R. S.; Timmons, C.; Li, G. Chem. Biol. Drug Des. 2006, 67, 101-114. doi:10.1111/j.1747-0285.2006.00347.x

39. Kizirian, J.-C. Chem. Rev. 2008, 108, 140-205. doi:10.1021/cr040107v 
40. Bennani, Y. L.; Hanessian, S. Chem. Rev. 1997, 97, 3161-3196. doi:10.1021/cr9407577

41. Cai, C.-Y.; Shu, X.-M.; Xu, H.-C. Nat. Commun. 2019, 10, 4953. doi:10.1038/s41467-019-13024-5

42. Ichikawa, S.; Dai, X.-J.; Buchwald, S. L. Org. Lett. 2019, 21 , 4370-4373. doi:10.1021/acs.orglett.9b01592

43. Mwenda, E. T.; Nguyen, H. M. Org. Lett. 2017, 19, 4814-4817. doi:10.1021/acs.orglett.7b02256

44. Xiao, L.; Zhao, Y.; Qiao, S.; Sun, Z.; Santoro, O.; Redshaw, C. Dalton Trans. 2020, 49, 1456-1472. doi:10.1039/c9dt04332b

45. Yu, L.; Somfai, P. Angew. Chem., Int. Ed. 2019, 58, 8551-8555. doi:10.1002/anie.201902642

46. Aurrecoechea, J. M.; Suero, R. ARKIVOC 2004, No. 14, 10-35. doi:10.3998/ark.5550190.0005.e02

47. McNally, A.; Prier, C. K.; MacMillan, D. W. C. Science 2011, 334, 1114-1117. doi:10.1126/science. 1213920

48. Kim, H.; Lee, C. Org. Lett. 2011, 13, 2050-2053. doi:10.1021/ol200455n

49. Narayanam, J. M. R.; Tucker, J. W.; Stephenson, C. R. J. J. Am. Chem. Soc. 2009, 131, 8756-8757. doi:10.1021/ja9033582

50. Kim, H.; Lee, C. Angew. Chem., Int. Ed. 2012, 51, 12303-12306. doi:10.1002/anie.201203599

51. Machrouhi, F.; Namy, J.-L. Tetrahedron Lett. 1999, 40, 1315-1318. doi:10.1016/s0040-4039(98)02673-2

52. VellemÄe, E.; Tsubrik, O.; Mäeorg, S.; Mäeorg, U. J. Chem. Res. 2006, 149-150. doi:10.3184/030823406776330792

53. Jiang, H.-F.; Huang, X.-Z. J. Supercrit. Fluids 2007, 43, 291-294. doi:10.1016/j.supflu.2007.07.005

54. Kumar, A.; Samuelson, A. G. Chem. - Asian J. 2010, 5, 1830-1837. doi:10.1002/asia.200900711

55. Rao, C. N.; Hoz, S. J. Am. Chem. Soc. 2011, 133, 14795-14803. doi:10.1021/ja205885q

56. Zhu, Y.; Buchwald, S. L. J. Am. Chem. Soc. 2014, 136, 4500-4503. doi:10.1021/ja501560x

57. CCDC 1991125 contain the supplementary crystallographic data for this article, which can be obtained free of charge from The Cambridge Crystallographic Data Centre.

58. Cheng, X.; Huang, W. Synlett 2016, 28, 148-158. doi:10.1055/s-0036-1588129

59. Jung, J.; Kim, J.; Park, G.; You, Y.; Cho, E. J. Adv. Synth. Catal. 2016, 358, 74-80. doi:10.1002/adsc.201500734

60. Park, G.; Yi, S. Y.; Jung, J.; Cho, E. J.; You, Y. Chem. - Eur. J. 2016, 22, 17790-17799. doi:10.1002/chem.201603517

61. Wang, P.-Z.; Chen, J.-R.; Xiao, W.-J. Org. Biomol. Chem. 2019, 17, 6936-6951. doi:10.1039/c9ob01289c

62. Gentry, E. C.; Knowles, R. R. Acc. Chem. Res. 2016, 49, 1546-1556. doi:10.1021/acs.accounts.6b00272

63. Hoffmann, N. Eur. J. Org. Chem. 2017, 1982-1992. doi:10.1002/ejoc.201601445

64. Jiang, H.; Studer, A. CCS Chem. 2019, 38-49. doi:10.31635/ccschem.019.20180026

65. Pannwitz, A.; Wenger, O. S. Chem. Commun. 2019, 55, 4004-4014. doi:10.1039/c9cc00821g

66. Weinberg, D. R.; Gagliardi, C. J.; Hull, J. F.; Murphy, C. F.; Kent, C. A.; Westlake, B. C.; Paul, A.; Ess, D. H.; McCafferty, D. G.; Meyer, T. J. Chem. Rev. 2012, 112, 4016-4093. doi:10.1021/cr200177j

\section{License and Terms}

This is an Open Access article under the terms of the Creative Commons Attribution License (http://creativecommons.org/licenses/by/4.0). Please note that the reuse, redistribution and reproduction in particular requires that the authors and source are credited.

The license is subject to the Beilstein Journal of Organic Chemistry terms and conditions: (https://www.beilstein-journals.org/bjoc)

The definitive version of this article is the electronic one which can be found at: doi:10.3762/bjoc. 16.114 